Egyptian Journal of Aquatic Biology \& Fisheries

Zoology Department, Faculty of Science,

Ain Shams University, Cairo, Egypt.

ISSN $1110-6131$

Vol. 23(2): 227 - 239 (2019)

www.ejabf.journals.ekb.eg

\title{
Effect of dietary Lacto cel-con probiotic on growth performance and hematology indices of fingerlings mono-sex Nile tilapia (Oreochromis niloticus)
}

\author{
Abdel-Moniem M. Yones ${ }^{1 *}$; Mohsen S. Hussein ${ }^{2}$; Mohamed W. Ali ${ }^{3}$ and \\ Abdel-Azem M. Abdel-Azem ${ }^{3}$ \\ 1- National Institute of Oceanography and Fishers, Fayoum, Egypt. \\ 2- Faculty of Agriculture, Al-Azhar University, Cairo, Egypt. \\ 3- Central Lab for Aquaculture Research, Abbasa, Abo hammed Sharkia, Egypt. \\ *Corresponding author: yones_55200010@yahoo.com
}

\section{ARTICLE INFO}

Article History:

Received: March 30, 2019

Accepted: April 20, 2019

Online: April 30, 2019

Keywords:

Sorghum level

Growth performance

Feed utilization

Nile tilapia

Blood parameters

Lactocel-con probiotic

\section{ABSTRACT}

A 120 day's feeding study was designed to study the effect of Lacto cel-con probiotic on the growth performance, hematology indices and body composition of Nile tilapia. Zea mays was substituted by sorghum in five formulated diets with inclusion levels of $(0,25,50,75$ and $100 \%)$. Fingerlings of mono-sex Nile tilapia with an initial weight of $(1.94 \pm 0.13 \mathrm{~g})$ were distributed in $1 \mathrm{~m}^{3}$ hapa fixed in earthen pond at stocking rate of 40 fish/replicate. The highest growth performance parameters in terms of (weight gain and specific growth rate) and nutrient utilization (feed conversion ratio and net protein utilization) were recorded by replacing 75 and $100 \%$ of Zea mays. On the other hand, blood indices include, Red blood Cell (RBCs) count, Lymphocyte, Hemoglobin concentration and Hematocrit value) displayed non-significant different among treatments. However, the values of White Blood Cell count (WBCs) were shown remarkable significance $(\mathrm{P}<0.05)$ with DS75 and DS100\% diets. No significance differences were obtained in carcass composition of tilapia fed in different sorghum levels. Results showed that sorghum meal supplemented with $(0.3 \%$ Lacto-cel con) can be entirely substituted up to $75 \%$ of corn meal in fingerlings of mono-sex Nile tilapia diets without negative effects on growth performance, nutrient utilization, some blood parameters and body composition. It's conclude that (DS75) is a potential protein-rich with low cost feeding diet for mono-sex Nile tilapia (Oreochromis niloticus).

\section{INTRODUCTION}

Tilapia is commonly cultured specie in the world, where its high source of animal proteins, essential amino acid, vitamins and minerals. Also fish can comfortably culture, highly adapt to environmental changes and is a vital species in developed countries (FAO,2010). Global tilapia production is expected to rise3-4 \% in 2018, reaching around 6.3 million tones (FAO, 2018). About 30\% from this production from China, although the highly production is intensified in little producing countries (FAO, 2018).

Sorghum (Sorghum bicolor L.) is the fifth most important cereal crop in the world commerce and grown in over 100 countries with different uses as animal feed, food, in brewery, and recently as a potential source of biofuel (Ali and Warren,1987 
and Araújo et al.,2017). Global sorghum production in 2017 is projected to be 60.46 million metric tons, and the U.S.A has been the highest producer with 9.42 million metric tons, then Nigeria, 6.55 million metric tons, and Ethiopia, 3.77 million metric tons (Araújo et al.,2017). United States of America was the top producer in 2009, with a harvest of 9.7 million metric tons. The next main sorghum producers with low quantities were India, Nigeria, Sudan and Ethiopia, respectively. Otherwise, the major regions for sorghum producing in the world from harvested quantities were Australia, Brazil, China, Burkina Faso, Argentina, Mali, Cameron, Egypt, Niger, United Republic of Tanzania, Chad, Mozambique, Venezuela and Ghana. The world sorghum harvested was 55.6 million tons in 2010 (FAO, 2010).

Sorghum is similar in chemical composition to corn (Zea mays) and has a nutritional value similar to other cereals (Aderolu et al.,2009). However, including anti-nutritional factors like tannins, phytates and cyanogenic glucosides among others could probably have effect on nutrient utilization and growth of fish. Processing of sorghum by different treatments such as soaking and wet-milling can removes high percent of these anti-nutrients.

The optimum inclusion level of carbohydrate led to improving growth parameters in fish and decreasing nitrogen waste with least cost diet (Mohanta et al., 2007). The use of carbohydrates is important in the fish diet so, protein or lipids are not catabolized for energy. Economically, it is more reasonable that protein can be utilized for muscle tissue synthesis not for produce metabolic energy (Oriro et al., 2014). Sparing protein by non-protein energy sources has been evident in a high range of species (Hemre, et al., 2002 ,Castro, et al.,2016 and Wu et al., 2016).

Until now, probiotics, point out as specific stimulant and a potent method, have highly received essential interest due to its benefits for limitation use of antibiotics, antimicrobial products and protection against infectious diseases as well as improving growth performance in aquaculture (Sahu et al.,2008a and Gao et al., 2013).

Recently more studies illustrated that diet supplementation with probiotic may have many beneficial effects on health status, immunostimulation and disease control (Panigrahi et al.,2009 and Oliva-Teles,2012). In the same manner, extensive studied on probiotics revealed a positive enhancement on growth and feed utilization in Nile tilapia Oreochromis niloticus (Lara-Flores et al.,2010). These benefits possibly as a result of that probiotic had capacity to stimulate and/or produce digestive enzymes, feed digestion and, in consequence, feed utilization efficiency. Indeed, some probiotics, like Bacillus species, produce a wide range of exoenzymes (amylase, protease, lipase and cellulase) that are very efficient in degradation of carbohydrates, proteins and lipids (Ray et al.,2012).

Alternatively, probiotics are now used in aquaculture as simple and safe additive to improve the health of the host. Probiotics have many advantages in aquaculture, such as modulating microbial colonization, enhancing growth, providing nutrients, improving immune responses, increasing digestive enzyme activities, improving feed utilization and digestibility, controlling diseases and improving water quality (Qi et al., 2009 and Merrifield et al., 2010a).

The present study was designed to detect the effect of different inclusion levels of sorghum supplemented with Lacto cel-con probiotic on the growth performance, feed efficiency, body proximate analysis and some blood parameters in fingerlings of mono-sex Nile tilapia (Oreochromis niloticus). 


\section{MATERIALS AND METHODS}

\section{Fish culture system}

Fingerlings of Nile tilapia (Oreochromis niloticus) were obtained from private tilapia hatchery at Fayoum Governorate, Egypt. They transferred to Shakshouk Research Station at Fayoum Governorate by using fish transport car held with pure oxygen source. The trial was conducted in earthen ponds of the station. The system consisted of 15 rectangular hapa designed as small ponds from small size nets (maga $60)$ and fixed with wood column from all sides. The volume of each unit was $1 \mathrm{~m}^{3}$ as $(1 \mathrm{~m} \times 2 \mathrm{~m} \times 0.5 \mathrm{~m})$. The earthen pond filled with agriculture drain water through cement channel. The running drain water were connected to the filled pond and changed as (100\% twice/week). Physicochemical characteristics of water earthen ponds were examined every two weeks according to (APHA, 2005). During the experimental study water quality values measured within the optimal ranges for this specie, where dissolved oxygen $\left(7.2 \pm 0.2 \mathrm{mg} \mathrm{dL}^{-1}\right)$, temperature $\left(28.42 \pm 1.2^{\circ} \mathrm{C}\right)$, salinity $(4.14 \pm 0.5)$ and $\mathrm{pH}(7.5 \pm 0.2)$ as recorded by (Bergheim, 2007).

This experiment was performed for a period of 120 days (from April $1^{\text {st }}, 2014$ till July $30^{\text {th }}$,2014). Two weeks of acclimatization period of fish on commercial diet containing (30\% crude protein) before starting the experimental. Fish were randomly distributed as density of 40 fingerlings in each pond with initial mean weight of $(1.94 \pm 0.13 \mathrm{~g})$ in three replicates for each treatment.

\section{Experimental diets}

Sorghum meal was obtained from local farm at Shahsouk-Fayoum, while the other ingredients purchased from El-Asil feed company-Dakahlea Governorate, Egypt. Sorghum was soaked with tap water along three days and then sun-dried before crushing. Ingredients were grinding into fine powder through a $150-\mu \mathrm{mmesh}$ before pelleting through California pelleted machine with $2 \mathrm{~mm}$ diameter. Five tested diets were prepared as: DC100 (which considered to be the control without sorghum meal (100\% corn), then sorghum meal was partially and totally replaced corn (Zea mayse) as follows: DS25 (25\% sorghum meal replacement), DS50 (50\% sorghum meal replacement), DS75 (75\% sorghum meal replacement) and DS100 (100\% sorghum meal replacement). Lacto cel-con was incorporated as $0.3 \%$ with the control and the four inclusion levels. The formulation and proximate composition of the practical diets are shown in (Table,1).

\section{Probiotics}

In the present experimental we used a commercial Lacto cel-con probiotic produced in China and their contents was as follows:

Lacto cel-con is mixture of Saccharomyces cervesia in purified mature live cells with the most beneficial intestinal micro flora-Lactobacillus acidophilus and Enterococcus faecium and is a dried natural product each $1 \mathrm{Kg}$ contains:

- $\quad$ Saccharomyces cerevesia $\left(2 \times 10^{12} \mathrm{CFU}\right)$

- Lactobacillus acidophilus $\left(100 \times 10^{9} \mathrm{CUF}\right)$

- Enterococcus faecium $\left(70 \times 10^{9} \mathrm{CUF}\right)$

- Carrier with mixture of ground yellow corn and gluten meal with a ratio of 3:1.

Guaranteed analysis:

Crude protein, minimum $\quad 18.00 \%$

Crude fat, minimum $\quad 3.00 \%$

Crude fiber, maximum $\quad 5.00 \%$

Saccharomyces cerevisiae, minimum 1 Trillion CFU's per $l b$.

Lactobacillus acidophilus, minimum $\quad 50$ Billion CFU's per $1 b$. 
Table 1. Formulation and proximate composition of experimental diets (\%DM basis).

\begin{tabular}{|c|c|c|c|c|c|}
\hline \multirow{2}{*}{$\begin{array}{l}\text { Items } \\
\text { Ingredients }\end{array}$} & \multicolumn{5}{|c|}{ Experimental diets\% } \\
\hline & DC100 & DS25 & DS50 & DS75 & DS100 \\
\hline Yellow-Corn & 33.0 & 24.75 & 16.5 & 8.25 & zero \\
\hline Sorghum & Zero & 8.25 & 16.5 & 24.75 & 33.0 \\
\hline Soya bean meal & 20.0 & 20.0 & 20.0 & 20.0 & 20.0 \\
\hline Wheat bran & 25.6 & 25.6 & 25.8 & 26.3 & 26.6 \\
\hline Glutein & 10.0 & 10.0 & 10.0 & 10.0 & 10.0 \\
\hline Fish meal & 5.7 & 5.7 & 5.5 & 5.0 & 4.7 \\
\hline Molasse & 1.0 & 1.0 & 1.0 & 1.0 & 1.0 \\
\hline Lactocel-con $\mathrm{g} / \mathrm{kg}$ & 0.3 & 0.3 & 0.3 & 0.3 & 0.3 \\
\hline Fish Oil & 3.0 & 3.0 & 3.0 & 3.0 & 3.0 \\
\hline Vit,Min Mix. $^{1}$ & 1.2 & 1.2 & 1.2 & 1.2 & 1.2 \\
\hline DL.Methionine & 0.2 & 0.2 & 0.2 & 0.2 & 0.2 \\
\hline Total & 100 & 100 & 100 & 100 & 100 \\
\hline \multicolumn{6}{|c|}{ Proximate composition of experimental diets (\%DM basis) } \\
\hline Dry matter $(\mathrm{DM})$ & 91.17 & 90.90 & 90.65 & 90.77 & 91.01 \\
\hline Crude protein $(\mathrm{CP})$ & 25.08 & 25.08 & 25.05 & 25.00 & 25.00 \\
\hline Ether extract (EE) & 10.80 & 9.50 & 10.60 & 9.90 & 9.40 \\
\hline Crude fiber $\quad(\mathrm{CF})$ & 6.27 & 6.59 & 6.55 & 6.89 & 6.56 \\
\hline $\mathrm{NFE}^{2}$ & 40.29 & 40.97 & 40.76 & 41.50 & 42.27 \\
\hline Ash & 17.56 & 17.71 & 16.79 & 16.36 & 16.37 \\
\hline Tannin $^{3}$ & - & 0.15 & 0.25 & 0.35 & 0.40 \\
\hline $\mathrm{GE}(\mathrm{Kcal} / \mathrm{kg})^{4}$ & 4089 & 3995 & 4088 & 4050 & 4034 \\
\hline $\mathrm{C} / \mathrm{P} \%$ ratio & 66.91 & 67.50 & 66.80 & 67.53 & 66.94 \\
\hline
\end{tabular}

1-Vitamin-mineral premix supplied the following (vitaminIUkg ${ }^{-1}$ diet and mineral $\mathrm{mg} / \mathrm{Kg}^{-1} \mathrm{mixture}$ ); retinyl acetate 0.67; ascorbic acid 120; cholecolciferol 0.1 ; tocopheryl acetate 34.2 ; menodione 22; thiamin 5.6; riboflavin 12; pyridoxine 4.5; calcioum panthothenate 14.1 ; p-aminobenzoic acid 40; cyanocobalamin 0.03 ; niacin 30 ; biotin 0.1 ; choline chloride 350 ; folic acid 1.5 ; inositol 50; canthaxanthin 10; butylated hydroxytoluene 1.5; butylated hydroxyanisol 1.5.; $\mathrm{CaHPO}_{4}, 2 \mathrm{H}_{2} \mathrm{O}$ 29.5; $\mathrm{Ca}\left(\mathrm{H}_{2} \mathrm{PO}_{4}\right) 2 \mathrm{H}_{2} \mathrm{O} 217 ; \mathrm{NaHCO}_{3}$ 94.5; $\mathrm{Na}_{2} \mathrm{SeO}_{3} 5 \mathrm{H}_{2} \mathrm{O}$ 0.011; Kci 100; Nacl 172.4; Ki 0.2; $\mathrm{Mgcl} 2$ 63.7; $\mathrm{MgSO}_{4} 34.3 ; \mathrm{MnSO}_{4} 2 ; \mathrm{FeSO}_{4} \mathrm{H}_{2} \mathrm{O} 10 ; \mathrm{CuSO}_{4} 5 \mathrm{H}_{2} \mathrm{O} 0.4 ; \mathrm{Zn} \mathrm{SO}_{4} 10$.

2-Calculated by differences, Nitrogen free extract (NFE) $=[100-(\mathrm{CP}+\mathrm{EE}+\mathrm{CF}+\mathrm{Ash})]$.

3-Tannin $=$ percent tannin on a catechin equivalent basis.

4- Estimated according to (NRC, 2011) by using these values,5.64,9.44 and $4.11 \mathrm{Kcal} / \mathrm{g}$ for protein, lipid and NFE, respectively.

\section{Chemical analysis}

Before the experiment, 30 fish from the initial fish were randomly chosen to determine initial body composition. After the end of the experimental, fish were starved for $24 \mathrm{hrs}$ prior to sample collection. Fish in each hapa weighed, counted and determine growth performance, feed efficiency and survival rate. Finally, 3 fish samples from each replicate were collected to determine the final carcass proximate composition. Analyses of diets and carcass composition were done by (AOAC,2006); dry matter determined by drying samples in an oven at $105{ }^{\circ} \mathrm{C}$ until constant weight; crude protein was measuring nitrogen by $(\mathrm{N} \times 6.25)$ after acid digestion (Kjeldahl method); crude lipid was determined through petroleum ether extraction using the (Soxhlet method); ash was detected by incineration in a furnace muffle at $550{ }^{\circ} \mathrm{C}$ for $16 \mathrm{~h}$, while nitrogen free extract (NFE) was calculated by difference. Gross energy in feed samples was calculated in chemical composition and estimated according to (NRC, 2011) by using these values: 5.64, 9.44 and 4.11 $\mathrm{Kcal} / \mathrm{g}$ for protein, lipid and NFE, respectively.

Tannin content of sorghum meal determined using a modified version of (Price et al.,1978). 


\section{Growth parameters}

equations:

Growth indices and feed utilization were measured by using the following

Body weight gain $\mathrm{BWG}=(\mathrm{FW}-\mathrm{IW})$.

FW=Final weight $(\mathrm{g}) . \mathrm{IW}=$ Initial weight $(\mathrm{g})$.

Specific growth rate SGR $(\% /$ day $)=($ Ln FW-Ln $1 W) / T \times 100$.

$\mathrm{Ln}=$ Natural logarithm $\mathrm{T}=$ period (days).

Condition factor $(\mathrm{K})=\mathrm{W} / \mathrm{L}^{3} \times 100$.

Where: $\mathrm{W}=$ fish weight $(\mathrm{g})$. $\mathrm{L}=$ fish standard length $(\mathrm{cm})$.

Feed conversion ratio $(\mathrm{FCR})=$ Feed intake $(\mathrm{g}) /$ Weight gain $(\mathrm{g})$.

PER $(\%)=$ Weight gain $(\mathrm{g}) /$ Protein intake $(\mathrm{g})$.

Net Protein utilization $($ NPU\%) $=($ Final body protein-Initial body protein/protein intake) $\times 100$.

Hepatosomatic index $($ HSI \%) $=($ liver weight $) /($ fish weight $) \times 100$.

\section{Blood analysis}

Three fish from each replicate were collected from the experimental hapa, and anesthetized by MS222 overdose and immediately bled. The blood was collected by using Vacutainer tubes (Becton-Dickinson, Rutherford, NJ, USA) provide with lithium heparin as anticoagulant to collect blood from the caudal artery and vein, then mixing and prepared to analysis. Standard haematological parameters were measured by (Blaxhall and Daisley,1973), as followed: Haemoglobin (Hb) with the cyanomethaemoglobin method, packed Cell Volume (PCV) by micro Haematocrit method, White Blood Cell (WBCs) with the improve Neubauer Counter, differential counts and lymphocytes) were done on blood film stained with may GrumwaldGiensa stain. Red blood cell (RBCs) was determined using the relationship between $\mathrm{Hb}$ and PCV (Miale,1982).

\section{Statistical analysis}

The results were presented as means $\pm \mathrm{SD}$ for three replicates. All data were exhibited one-way analysis (ANOVA) to test the effect of different sorghum levels and probiotic on various performance, feed utilization, and blood values of experimental fish according to (Snedecore and Cochran,1987). Tukey multiple range tests were applied to detect the significant differences between the means of treatments (Zar,1999). All analysis were performed using SPSS version 20,(2016) SPSS Institute, Cary, NC, USA).

\section{RESULTS}

\section{Chemical composition of diets}

Our results show that the tested diets were similar in their protein contents ranging from (30.04 to 30.27\%) and growth energy contents ranging from (19.73 to19.96 $\mathrm{MJ} \mathrm{kg}^{-1}$ diets) as presented in (Table, 1).

\section{Growth performance}

The growth performance values revealed that mean of initial weights of the experimental ranged between $(1.75 \pm 0.1-2.09 \pm 0.11)$ for weight and $(1.50$ $\pm 0.11-2.60 \pm 0.12$ ) in length as shown in (Table, 2, Figs.1\&2). The growth values show no significant differences among groups point to the complete homogeneity among the experimental fish at the onset of the experiment. 
Table 2: Growth performance and feed utilization of tilapia fed on different experimental diets (Mean \pm SD n=9).

\begin{tabular}{llllll}
\hline \multirow{2}{*}{ Parameters } & \multicolumn{5}{c}{ Experimental diets\% } \\
\cline { 2 - 6 } & \multicolumn{1}{c}{ DC100 } & \multicolumn{1}{c}{ DS25 } & \multicolumn{1}{c}{ DS50 } & \multicolumn{1}{c}{ DS75 } & DS100 \\
\hline Init. fish weight (g) & $1.90^{\mathrm{a}} \pm 0.11$ & $2.09^{\mathrm{a}} \pm 0.11$ & $1.90^{\mathrm{a}} \pm 0.12$ & $1.75^{\mathrm{a}} \pm 0.11$ & $2.01^{\mathrm{a}} \pm 0.12$ \\
Final fish weight (g) & $56.00^{\mathrm{d}} \pm 4.19$ & $60.25^{\mathrm{c}} \pm 5.05$ & $61.85^{\mathrm{c}} \pm 4.35$ & $69.20^{\mathrm{a}} \pm 5.20$ & $66.95^{\mathrm{b}} \pm 5.25$ \\
Init.fish length(cm) & $2.00^{\mathrm{a}} \pm 0.11$ & $2.6^{\mathrm{a}} \pm 0.12$ & $2.50^{\mathrm{a}} \pm 0.12$ & $1.50^{\mathrm{a}} \pm 0.10$ & $2.50^{\mathrm{a}} \pm 0.13$ \\
Final fish length (cm) & $15.70^{\mathrm{a}} \pm 0.32$ & $16.00^{\mathrm{a}} \pm 0.34$ & $16.10^{\mathrm{a}} \pm 0.32$ & $16.50^{\mathrm{a}} \pm 0.34$ & $16.56^{\mathrm{a} \pm 0.32}$ \\
Total weight gain (g) & $54.10^{\mathrm{d}} \pm 4.75$ & $58.16^{\mathrm{d} \pm 4.66}$ & $59.95^{\mathrm{c}} \pm 4.55$ & $67.45^{\mathrm{a}} \pm 4.26$ & $64.94^{\mathrm{b}} \pm 4.54$ \\
SGR (\%/ day) & $1.22^{\mathrm{b}} \pm 0.02$ & $1.21^{\mathrm{b}} \pm 0.02$ & $1.26^{\mathrm{ab}} \pm 0.04$ & $1.33^{\mathrm{a}} \pm 0.04$ & $1.27^{\mathrm{ab}} \pm 0.05$ \\
Condition factor(K) & $1.44^{\mathrm{b}} \pm 0.02$ & $1.47^{\mathrm{ab}} \pm 0.02$ & $1.48^{\mathrm{ab}} \pm 0.04$ & $1.54^{\mathrm{a}} \pm 0.01$ & $1.47^{\mathrm{ab}} \pm 0.03$ \\
Feed intake (g/fish) & 115.65 & 122.14 & 123.46 & 124.37 & 122.53 \\
Feed conversion ratio & $2.14^{\mathrm{b}} \pm 0.11$ & $2.10^{\mathrm{b}} \pm 0.12$ & $2.06^{\mathrm{b}} \pm .04$ & $1.84^{\mathrm{a}} \pm 0.13$ & $1.89^{\mathrm{a}} \pm 0.12$ \\
Protein efficiency ratio & $1.86^{\mathrm{b}} \pm 0.11$ & $1.89^{\mathrm{b}} \pm 0.12$ & $1.93^{\mathrm{b}} \pm 0.12$ & $2.17^{\mathrm{a}} \pm 0.11$ & $2.12^{\mathrm{a}} \pm 0.13$ \\
Net protein utilization (\%) & $29.24^{\mathrm{b}} \pm 1.2$ & $29.96^{\mathrm{b}} \pm 1.4$ & $28.41^{\mathrm{b}} \pm 1.2$ & $29.31^{\mathrm{b}} \pm 1.6$ & $30.78^{\mathrm{a}} \pm 1.4$ \\
Hepatosomatic index (HSI \%) & $2.1^{\mathrm{a} \pm 0.02}$ & $2.2^{\mathrm{a}} \pm 0.04$ & $2.3^{\mathrm{a}} \pm 0.02$ & $2.2^{\mathrm{a}} \pm 0.04$ & $2.4^{\mathrm{a}} \pm 0.05$ \\
\hline
\end{tabular}

Means in the same raw with different super script letters are significantly different $(\mathrm{P}<0.05)$.

However, the final weight gain, specific growth rate and condition factor showed significance difference $(\mathrm{P}<0.05)$ between treatments. Furthermore, the highest values in previous parameters were obtained with the fish fed up to 75\% sorghum meal (DS75\%) compared with corn diet (control) and other experimental diets. In the same manner, feed utilization from feed intake, feed conversion ratio, protein efficiency ratio and net protein utilization were significant difference between treatments $(\mathrm{P}<0.05)$. The elevated parameters of feed conversion ratio and other values of feed utilization were observed with fish fed (DS75\%) as illustrated in (Fig.,3). However, the hepatosomatic index (HSI) show no significant differences between dietary treatments.

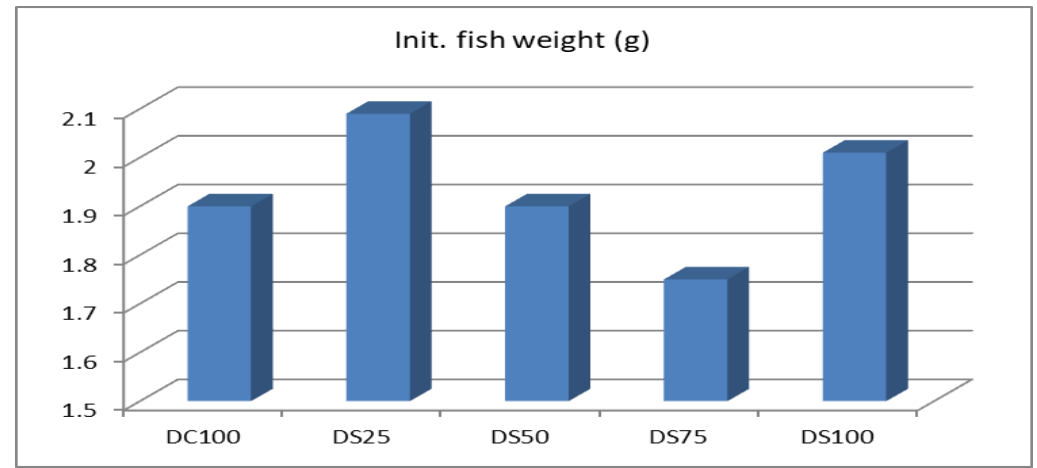

Fig. 1: Initial fish weight of experimental fish.

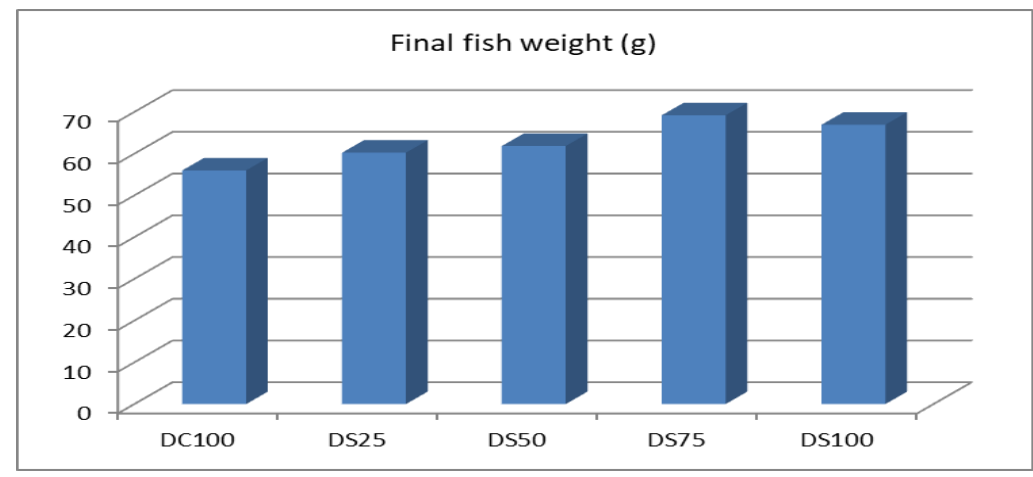

Fig. 2: Final average weight of fish fed experimental diets. 


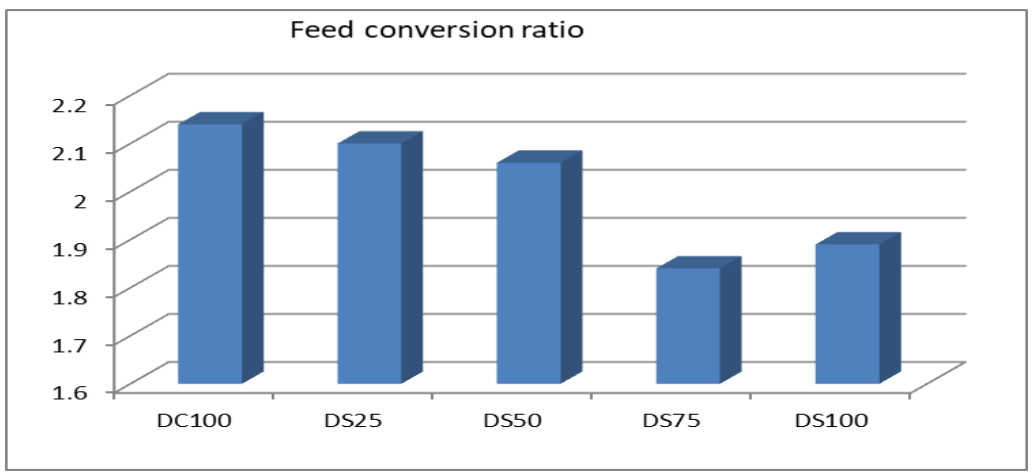

Fig. 3: Feed conversion ratio of experimental diets.

\section{Blood parameters}

As presented in $($ Table, 3$)$, there was a significance increased $(\mathrm{p}<0.05)$ in white blood cells (WBCs) with increasing sorghum meal (DS75 and DS100) and the lowest value was obtained with $25 \%$ sorghum meal diet. However, RBCs, Lymphocyte, Hemoglobin and Hematocrit ratios were not showed significant differences between experimental diets.

Table 3: Blood parameters of tilapia fed on different experimental diets (Mean \pm SD n=9).

\begin{tabular}{lccccc}
\hline \multirow{2}{*}{ Parameters } & \multicolumn{5}{c}{ Experimental diets\% } \\
\cline { 2 - 6 } & DC100 & DS25 & DS50 & DS75 & DS100 \\
\hline WBCs $(106 / \mathrm{mm})$ & $74.20^{\mathrm{b}} \pm 0.88$ & $73.40^{\mathrm{b}} \pm 0.82$ & $76.34^{\mathrm{a}} \pm 0.74$ & $78.72^{\mathrm{a}} \pm 0.71$ & $78.12^{\mathrm{a}} \pm 0.76$ \\
RBCs $\left(10^{3} / \mathrm{ml}^{3}\right)$ & $2.56^{\mathrm{a}} \pm 0.06$ & $2.42^{\mathrm{a}} \pm 0.05$ & $2.49^{\mathrm{a}} \pm 0.04$ & $2.67^{\mathrm{a}} \pm 0.05$ & $2.46^{\mathrm{a}} \pm 0.04$ \\
Lymphocyte & $91.84^{\mathrm{a}} \pm 1.40$ & $91.20^{\mathrm{a}} \pm 1.42$ & $92.22^{\mathrm{a}} \pm 1.35$ & $93.46^{\mathrm{a}} \pm 1.34$ & $91.43^{\mathrm{a}} \pm 1.34$ \\
Hemoglobin $(\mathrm{g} / \mathrm{dL})$ & $9.33^{\mathrm{a}} \pm 0.42$ & $9.26^{\mathrm{a}} \pm 0.52$ & $9.12^{\mathrm{a}} \pm 0.45$ & $9.20^{\mathrm{a}} \pm 0.35$ & $9.32^{\mathrm{a}} \pm 0.45$ \\
Hematocrit $(\%)$ & $34.25^{\mathrm{a}} \pm 0.67$ & $34.66^{\mathrm{a}} \pm 0.57$ & $34.34^{\mathrm{a}} \pm 0.23$ & $34.57^{\mathrm{a}} \pm 0.43$ & $34.44^{\mathrm{a}} \pm 0.43$ \\
\hline
\end{tabular}

Means in the same raw with different super script letters are significantly different $(\mathrm{P}<0.05)$.

\section{Carcass composition}

The whole body composition of fish was presented in (Table 4). As shown no significance difference $(\mathrm{P}>0.05)$ was detected in dry matter, crude protein ether extract and ash between treatments.

Table 4: Whole body analysis (Mean \pm SD $n=9$ ) of tilapia fed on the experimental diets (\%w/w basis).

\begin{tabular}{lccccc}
\hline \multirow{2}{*}{ Chemical analysis } & \multicolumn{5}{c}{ Experimental diets\% } \\
\cline { 2 - 6 } & DC100 & DS25 & DS50 & DS75 & DS100 \\
\hline Dry matter & $27.33 \pm 0.40$ & $27.35 \pm 0.20$ & $27.56 \pm 0.25$ & $28.02 \pm 0.15$ & $27.82 \pm 0.25$ \\
Crude protein (CP) & $15.49 \pm 0.03$ & $15.68 \pm 0.05$ & $15.46 \pm 0.10$ & $15.45 \pm 0.10$ & $15.32 \pm 0.10$ \\
Ether extract (EE) & $5.32 \pm 0.20$ & $5.51 \pm 0.30$ & $5.97 \pm 0.25$ & $6.47 \pm 0.10$ & $6.46 \pm 0.20$ \\
Ash & $6.52 \pm 0.16$ & $6.16 \pm 0.10$ & $6.13 \pm 0.07$ & $6.10 \pm 0.18$ & $6.04 \pm 0.17$ \\
\hline
\end{tabular}

\section{DISCUSSION}

The effects of probiotics have been extensively investigated since its onset use in aquaculture, and their beneficial on growth and immunity for aquatic animals have been confirmed.

The utilization of probiotics in aquaculture has increased during recent years. Newly, a specific type, heat-killed or inactivated probiotics has been applied as a promoter or an immuno-stimulant/immuno-biotic to promote growth performance, improve feed utilization, enhance none-specific immune responses, resistance to stress and protection against bacterial pathogens of aquatic animals (Dawood et al., 2016b). 
In the current study, the dietary supply of Lacto cel-con significantly enhanced the growth and feed efficiency of tilapia in terms of (weight gain, specific growth rate, condition factor, feed conversion ratio, protein efficiency ratio and net protein utilization) compared to those feded without Lacto cel-con diets. Similar results were detected in tilapia Oreochromis niloticus diet supplemented with Lacto cel-con by (El Zayat, 2014 and Hussein et al., 2016) and other type of probiotic (Khattab et al.,2004, EL-Haroun et al.,2006, Eid and Mohamed, 2008, Olmos et al., 2011, Chiu and Liu, 2014, Ridha and Azad, 2016, Lopez et al., 2016, Dawood et al., 2016b, Dawood et al., 2016c, Dawood et al., 2017 and Nguyen et al., 2019).

The above observations were generally demonstrated that the growth promotion of fish was likely attributed to the positive effects of inactivated and/or dead (killed) probiotic bacteria. Inactivated compounds enhanced the concentration of extracellular enzymes secreted by the gut microflora and improved the digestibility (Dawood et al.,2015c). Otherwise, enhanced the immune responses, resulting an improvement in health status (Rodriguez-Estrada et al.,2013 and Zhou et al.,2010). Other researchers suggested that the use of these compounds, induce the secretion of the intestinal brush border enzymes by intestinal epithelial cells together with extracellular enzymes synthesized by intestinal microbes (Kesarcodi-Watson et al.,2008). However, the probiotic roles in synthesis and utilization nutrients in fish have not been completely elucidated (Abumourad et al.,2013 and Dawood et al.,2016a), and the metabolism of Lacto cel-con related to elevated growth and feed efficacy in tilapia, which takes place in the gastro intestinal tract, is possibly complicated and need further studies.

In the present trial it's clear that the sorghum meal can be used up to $33 \%$ to replace $75 \%$ of corn Zea mays without negative effect on growth parameters and feed efficiency of fingerlings tilapia, concept the lowering of corn from $100 \%$ to $25 \%$ by substituting with sorghum meal. The high inclusion level of sorghum in the different diets was not affected by its palatability. This might be attributed to the soaking and heating during pelting of sorghum seeds prior to use in tilapia diets. This finding is in agree with (Fagbenro,1999, Francis et al.,2001, Siddhuraja et al.,2003 and Obe, 2014), they reported that the reduction in anti-nutrient by various processing techniques resulted to better palatability and growth in fish. The present results are in agree with the previous results in tilapia, which revealed the ability of this specie to utilize up to $40 \%$ of dietary starch sources (maize or sorghum) as recorded by (Yones, 2005, Yones and Metwalli, 2016, Abd-El-Azem, 2016 and Hussein et al., 2016). However, Wilson et al.,(2003) reported a high inclusion up to (44\% of diet) from low tannin sorghum $0.4 \%$ tannin in feeding of Nile tilapia. In the present study, the normal relative liver weight (HSI) revealed that the fish was well being utilized this source of carbohydrate to provide energy, probably as a consequence of the good utilization of $\mathrm{CHO}$ coupled with the using of Lacto cel-con in feeding strategy.

Data showed that the blood parameters of fingerlings tilapia from (Hematocrit, Hemoglobin, Red blood cell (RBCs), and Lymphocyte) were not affected with sorghum inclusion levels and similar with the recorded values in tilapia (Akinrotimi et al., 2012 and Hussein et al.,2016). In contrast significance differences and high levels of WBCs were obtained by using Lacto cel-con in different groups as a result of immunity effect. The data obtained are in line with the findings of using probiotics as immuno-stimulants to enhance the non-specific immune system of the host and protected against stress (Hussein et al.,2016).

The whole chemical composition of fish was not affected by probiotic and inclusion levels of sorghum and these values were in accordance with the previous 
results (Anderson et al., 1984,Al-Asgah and Alli, 1994,Al-Ogaily and Alli., 1996, Solomon et al., 2007, Yones and Metwalli, 2016 and Hussein et al.,2016).

\section{CONCLUSION}

The use of sorghum meal to replace up to $75 \%$ of corn in diet supplemented with $0.3 \%$ Lacto cel-con probiotic didn't shown any adverse effects on growth performance, feed utilization, blood parameters and chemical composition of monosex Nile tilapia fingerlings. It's also clear the benefit effect of probiotic in the previous parameters. The present results confirm that sorghum meal can be substituted instead of corn meal in diet formulation as alternative and cheap carbohydrate source in tilapia feeding. Otherwise, more studies on sorghum digestibility will be effective to detect the adequate inclusion level in tilapia diet. In the same manner, further research is still needed to detect the role of probiotics (mode of action) on digestibility, immune response and stress resistance. It is also important to define the optimum levels of probiotic, which can be used in tilapia diets to avoid any adverse effects on fish culture.

\section{REFERENCES}

Abd-El-Azem (2016). Effect of partial or complete replacement of yellow corn (Zea mays) by sorghum (Sorghum bicolor) and Lacto cel- con as probiotic on growth performance, feed utilization and body composition in mono sex Nile tilapia (Oreochromis niloticus). Msc. Thesis Faculty of agriculture, Al-Azhar Univ. Cairo.

Abumourad, M. K., Abbas, I., Awaad, W. T., Authman, E. S., Shafei, M. M. N., Sharaf, K. E., Ibrahim, O. M., Sadek, G. A. and Elsayed, Z. I. S. H. (2013). Evaluation of Lactobacillus plantarum as a probiotic in aquaculture: Emphasis on growth performance and innate immunity. J. Appl. Sci. Res., 9:572-582.

Aderoul, A. Z., Kuton, M. P.and Odu-Onikosi, S. G. (2009). Substitution effect of sorghum meal for maize meal in the diet of catfish (Clarias gariepinus, Burchell) juvenile. Res. J. Fish. Hydrobiol., 4(2):41-45.

Akinrotimi, Q. A., Gabriel, U. U. and Ariweriokuma, S. V. (2012). Changes in blood parameters of Tilapia exposed different salinity levels. Journal of Environmental Engineering and Technology, 1(2):4-12.

Al-Asgah,N.A. and Alli, A. (1994). Feeding of various carbohydrate sources on the growth performance and nutrient utilization in Oreochromis niloticus. Agribiol. Res., 47:1-12.

Ali, M.K. and Warren, H. L. (1987). Physiological races of Colletotrichum graminicola on sorghum. Plant Dis, 1:402-404.

Al_Ogaily,S.M.,N.A and A.Ali,(1996). Effect of feeding different grain sources on the growth performance and body composition of Tilapia (Oreochromis niloticus (L). Aquaculture Res., 27:523-529.

Anderson, J., Jackson, A.J., Matty, A.J. and Capper, B.S. (1984). Effects of dietary carbohydrate and fibre on the tilapia Oreochromis niloticus (Linn.). Aquaculture, 37(4):303-314.

AOAC, 2006. Official Methods of Analysis of AOAC International, $18^{\text {th }}$ ed. Rev.1. AOAC International. (Gaithersburg, MD, USA.).

APHA(2005).Standard Methods for the Examination of Water and Wastewater, 21st edn. APHA, Washington, DC, USA. 
Araújo, K., Mahajan, D. and Kerr, R., (2017). Global Biofuels at the Crossroads: An overview of technical, policy, and investment complexities in the sustainability of biofuel development. Agriculture, 7:32.

Bergheim, A. (2007). Water quality criteria I recirculation system for tilapia. IRISInternational Research Institute of Stavanger,4068, Norway.

Blaxhall, P. C. and Daisley, K. W. (1973). Routine hematological methods for use with fish blood. Journal of fish Biology, 5(6):771-781.

Castro,C.,Corraze,G.Firmino-Diogenes, A., Larroquet, L.,Pansert,S. and OlivaTeles,A. (2016). Regulation of glucose and lipid metabolism by dietary carbohydrate levels and lipid sources in gilthead sea bream juvenile. Brit. J. Nutr.,116:19-34.

Chiu,K. and Liu,W. (2014). Dietary administration of the extract of Rhodobacter sphaeroides WL-APD911enhances the growth performance and innate immune responses of seawater red tilapia (Oreochromis mossambicus $\times$ Oreochromis niloticus). Aquaculture, 418-419:32-38.

Dawood, M.A.O., Koshio, S., Ishikawa, M. and Yokoyama, S. (2015c). Effects of heat killed Lactobacillus plantarum (LP20) supplemental diets on growth performance, stress resistance and immune response of red sea bream, Pagrus major. Aquaculture, 442:29-36.

Dawood, M.A., Koshio, S., Ishikawa, M., El-Sabagh, M., Esteban, M.A.and Zaineldin, A.I., (2016a). Probiotics as an environment-friendly approach to enhance red sea bream, Pagrus major growth, immune response and oxidative status. Fish Shellfish Immunol., 57:170-178.

Dawood, M.A., Koshio, S., Ishikawa, M. and Yokoyama, S.(2016b). Immune responses and stress resistance in red sea bream, Pagrus major, after oral administration of heat killed Lactobacillus plantarum and vitamin C. Fish Shellfish Immunol., 54: 266-275.

Dawood, M.A.O., Koshio, S., Ishikawa, M., Yokoyama, S., (2016c). Effects of dietary inactivated Pediococcus pentosaceus on growth performance, feed utilization and blood characteristics of red sea bream, Pagrus major juvenile. Aquacul. Nutr., 22:923-932.

Dawood, M.A., Koshio, S., El-Sabagh, M., Billah, M.M., Zaineldin, A.I., Zayed, M. M. and Omar, A. A. E.- D. (2017). Changes in the growth, humoral and mucosal immune responses following $\beta$-glucan and vitamin $\mathrm{C}$ administration in red sea bream, Pagrus major. Aquaculture, 470: 214-222.

Eid, A. and Mohamed, K. A. (2008). Effect of using probiotic as growth promoter in commercial diets for monosex Nile tilapia (Orechromis niloticus) fingerlings. $8^{\text {th }}$ International Symposium on Tilapia in aquaculture, Cario, Egypt, 12-14Oct., pp:241-253. (ISBN:978-1-888807-18-9).

EL-Haroun E.R., Goda A.M. and Chowdhury, M.A. (2006). Effect of dietary probiotic Biogen supplementation as a growth promoter on growth performance and feed utilization of Nile tilapia, Oreochromis niloticus(L.). Aquac. Res.,37:147-1480.

El- Zayat, A.M.(2014). Study the effect of some probiotics on production of fish farms. Ph.D. Thesis. Faculty of agriculture, Al-Azhar Univ.Cairo.

Fagbenro, O. A. (1999). Comparative evaluation of heat processed winged bean (Psophocarpus tetragonolobus) meals as partial replacement for fishmeal in diets for African catfish (Clarias gariepinus). Aquaculture,170: 297-305.

FAO (2018).Globefish-Analysis and information on world fish trade.

FAO (2010). FAO Yearbook. Fishery and aquaculture statistics. 
Francis, G., Makkar,H. P. S. and Becker, K. (2001). Anti-nutritional factors present in plant derived alternate fish feed ingredients and their effects in fish. Aquacultre, 199:197-227.

Gao, Q. X., Shi, Z. H., Peng, S. M. (2013). Probiotics in Aquaculture : Recent Progress and Outlook. Marine Fisheries., 35: 364-372.

Hemre, G. I., Mommsen, T. P. and Krogdahl, A. (2002). Carbohydrate in fish nutrition; effects on growth glucose metabolism and hepatic enzymes. Aquacult. Nut.,7:1-10.

Hussein,M.S.,Yones, A.M, Ali, M.W. and Abd El-Azem, A. (2016). Effect of sorghum replacement and probiotic on growth performance and feed utilization of Nile tilapia (Orechromis niloticus). Egypt. J. Aquat. Biol. and Fish., 20 (2): 113-121.

Khattab,Y.A., Shalaby,A.M., Sharaf,S.M., El-Marakby, H.I. and Rizkalla, E.H. (2004). The physiological changes and growth performance of the Nile tilapia Oreochromis niloticus after feeding with Biogen as growth promoter. Egypt, J. Aquat. and Fish.,8:45-158.

Kesarcodi-WatsonA., Kaspar,H., Lategan, M.J. and Gibson, L. (2008). Probiotics in aquaculture: the need, principles and mechanisms of action and screening processes. Aquaculture, 274: 1-14.

Lara-Flores,M.,Olivera-Castillo, L. and Olvera-Novoa, M.A. (2010). Effect of the inclusion of a bacterial mix (Streptococcus faecium and Lactobacillus acidophilus), and the yeast (Saccharomyces cerevisiae) on growth, feed utilization and intestinal enzymatic activity of Nile tilapia (Oreochromis niloticus). International Journal of Fisheries and Aquaculture, 2(4):93-101.

Lopez, L. M., Soto, J. O., Idaly, T. E., Ibarra, M. F., Ochoa, L., Drawbridge, M. and Peres, H. (2016). Evaluation of carbohydrate-to-lipid ratio in diets supplemented with Bacillus subtilis probiotic strain on growth performance, body composition and digestibility in juvenile white seabass (Atractoscion nobilis, Ayres 1860). Aquaculture Research, 47:1864-1873.

Merrifield, D.L., Dimitroglou, A., Foey, A., Davies, S.J, Baker, R.M.T., Bogwald, J., Castex, M. and Ringo, E. (2010a). The current status and future focus of probiotic and prebiotic applications for salmonids. Aquaculture, 302:1-18.

Miale,T.D.,Stenke, L.A., Lindblom,J.B.,Sjogren,A.M.,Reizentstein,P.G.,Uden, A.M. and Lawson, D.L.(1982). Surface la-like expression and MLR-stimulating capacity for immunotherapy and prognosis. Acta Hematologica, 68(1):3-13.

Mohanta, K. N., Mohanty, S. N. and Jena, J.K. (2007). Protein-sparing effect of carbohydrate in silver barb, Puntius gonionotus fry. Aquaculture Nutrition, 13:311-31.

National Research Council, NRC. (2011). Nutrient Requirements of fish and shrimp. National Academy Press, Washington, D. C., USA.

Nguyen,V. N., Onoda, S., Khanh, T. V., Hai, P. D.,Trung, N. T., Hoang, L. and Koshio, S. (2019). Evaluation of dietary Heat-killed Lactobacillus plantarum strain L-137 supplementation on growth performance, immunity and stress resistance of Nile tilapia (Oreochromis niloticus). Aquaculture, 498:371-379.

Obe, B.W. (2014). Growth performance and nutrient utilization of Catfish Hybrid (Heterobranchus bidorsalis $\times$ Clarias gariepinus) Fed Fermented Sorghum (Sorghum bicolor) Waste Meal Diets. International Journal of App. Sci. and Techn.,4:1-7.

Oliva-Teles, A. (2012).Nutrition and health of aquaculture fish: a review. Journal of Fish Diseases 35: 83-108. 
Olmos, S.J., Ochoa, S.L., Paniagua-Michel, J. and Contreras, F.R. (2011). Functional feed assessment on Litopenaeus vannamei using 100\% fish meal replacement by soybean meal, high levels of complex carbohydrates and Bacillus probiotic strains. Marine Drugs, 9:119-1132.

Oriro, O. M. and Sadiku, S. O. M. (2014). Effects of carbohydrate sources on the growth and body compositions of African catfish (Clarias gariepinus). Int. J. Fish. Aquac., 6: 55-61.

Panigrahi, A., Azad, I. S., Das, B. K., Dandpat, J., Das, G., Behera, S. and Mishra, S. S. (2009). Probiotic induced immunomodulation: investigation into the cellular and molecular mechanism involved. Res. J. Biotechnol., 4:7-13.

Price, M. L.VanScoyoc, S. and Butler, L. G. (1978). A critical evaluation of the vanillin reaction as an assay for tannin in sorghum grain. Journal of Agriculture and Food Chemistry, 26 (5): 1214-1218.

Qi, ZZ, Zhang XH, Boon N and Bossier, P. (2009). Probiotics in aquaculture of China-current state, problems and prospect. Aquaculture, 290:5-21.

Ray,A.K., Ghosh, K. and Ringo, E.(2012).Enzyme-producing bacteria isolated from fish gut: a review. Aquaculture Nutrition,18:465-492.

Ridha, M.T. and Azad, I.S. (2016). Effect of autochthonous and commercial probiotic bacteria on growth, persistence, immunity and disease resistance in juvenile and adult Nile tilapia Oreochromis niloticus. Aquaculture Research, 47:2757-2767.

Rodriguez-Estrada, U., Satoh, S., Haga, Y., Fushimi, H. and Sweetman, J. (2013). Effects of inactivated Enterococcus faecalis and mannan oligosaccharide and their combination on growth, immunity, and disease protection in rainbow trout. North American J. Aquacul., 75:416-428.

SPSS Inc. (Released 2016). SPSS Statistics for Windows, Version, 20, Chicago: SPSS Inc, USA.

Sahu, M.K.,Swarnakumar, N.S., Sivakumar, K., Thangaradjou, T. and Kannan, L. (2008a). Probiotics in aquaculture: importance and future perspectives. Indian J. Microbiol., 48:299-308.

Snedecore, W. G. and.Cochran,W. C. (1987). Statistical Methods. Iowa state Univ., USA.

Siddhuraju, P., Beeker, K. and Richter, N.(2003). Evaluation of nutritional quality of moringa (Moringa oleifera Lam) leaves as an alternative protein source for Nile tilapia (Oreochromis niloticus). Aquaculture, 217:599-611.

Solomon, S.G.Tiamiyu, L.O and Agaba, U.J. (2007). Effect of Feeding Different Grain Sources on the Growth Performance and Body Composition of Tilapia, (Oreochromis niloticus) Fingerlings Fed in Outdoor Hapas. Pakistan Journal of Nutrition, 6 (3):271-275, 2007.

Wilson, R.P. (2003). Utilization of dietary carbohydrate by fish. Aquaculture,124:6780.

Wu, C., Ye, J., Gao, J.E., Chen, L., Lu, Z. (2016). The effects of dietary carbohydrate on the growth, antioxidant capacities, innate immune responses and pathogen resistance of juvenile Black carp Mylopharyngodon piceus. Fish Shellfish Immunol.49: 132-142.

Yones, A.M. (2005). Effect of dietary sorghum as carbohydrate source and two lipid levels in feeds of gilthead sea bream (Sparus aurata) on its growth performance. Egypt. J. Aquat. Biol. and Fish., 9:85-99.

Yones, A. M. and Metwalli, A. A. (2016). Dietary sorghum starch influences growth performance, apparent digestibility and some hepatic enzyme activities of 
carbohydrate metabolism in hybrid red tilapia (Oreochromis mossambicus $\times O$. niloticus) fingerlings. International J. Fish. Aquacult. Res., 1,:1-16.

Zar, J. H. (1999). Bio-statistical Analysis, $4^{\text {th }}$ edn. Prentice Hall, New Jersey, USA, $663 p p$.

Zhou, X., Tian, Z., Wang, Y., Li, W., (2010). Effect of treatment with probiotics as water additives on tilapia (Oreochromis niloticus) growth performance and immune response. Fish Physiol. Biochem. 36: 501-509.

\footnotetext{
ARABIC SUMMARY
تأثثير تغذية الاكتو-سيلكون بروبيوتك على معدلات الأداء ومؤشرات الدم لإصبعيات أسماك البلطى النيلى

تأثير تغذية الاكتو-سيلكون بروبيوتك على معدلات الأداء ومؤشرات الام لإصبعيات أسماك البلطى النيلى

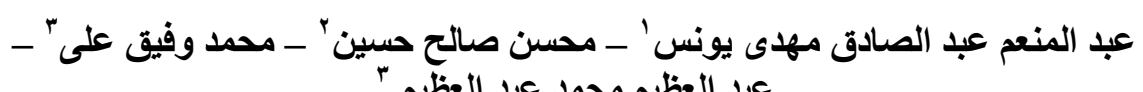

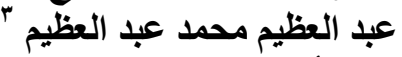

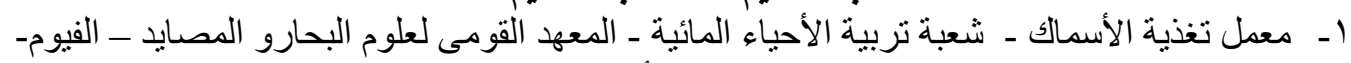

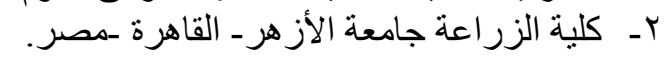

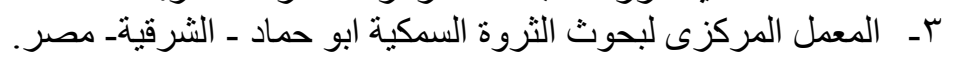

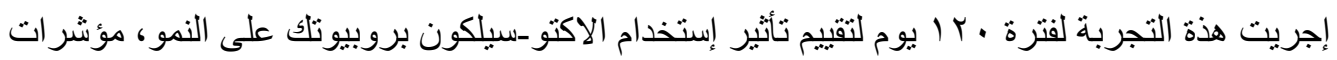

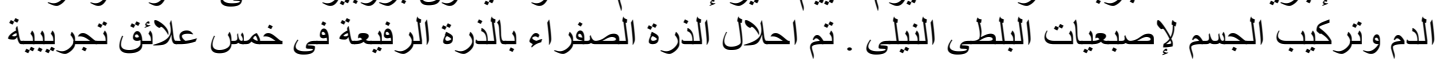

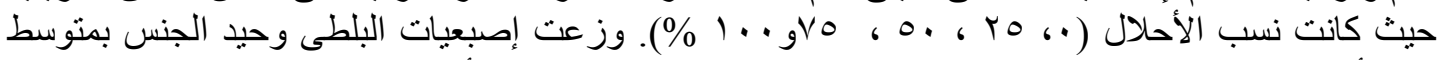

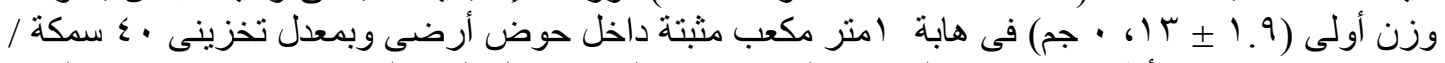

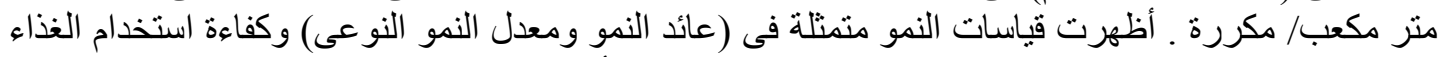

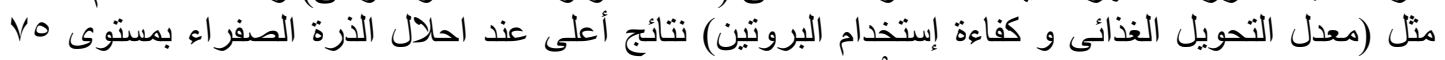

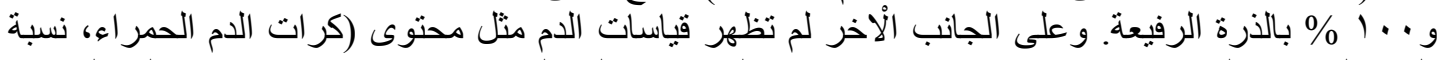

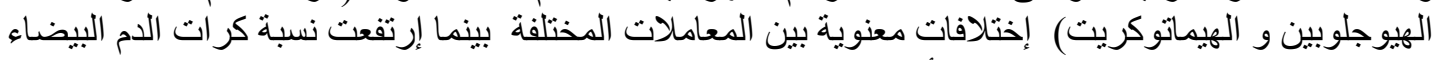

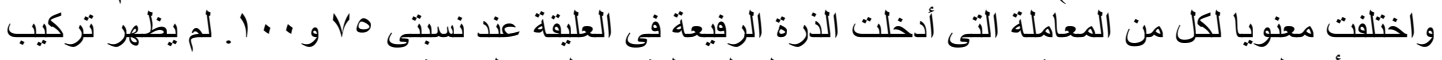

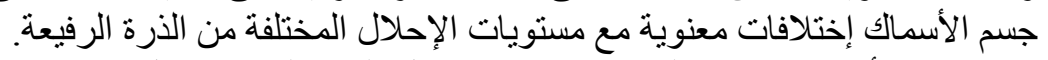

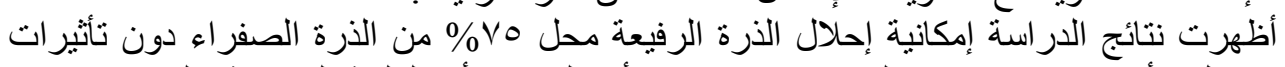

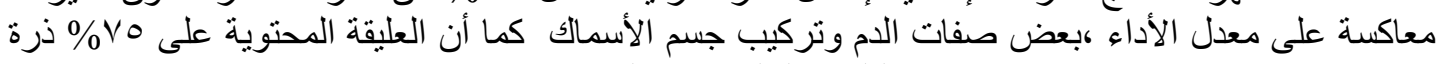
رفيعة كانت اقتصادية فى تغذية إصبعيات البلطى النيلى وحيد الجنس.
} 